\title{
Light in intermediate acclimatization of in vitro germinated seedlings of Dendrobium phalaenopsis Deang Suree
}

\author{
Luz na aclimatização intermediária de mudas germinadas in vitro de Dendrobium phalaenopsis \\ Deang Suree
}

\author{
José Carlos Sorgato $^{I^{*}}$ Yara Brito Chaim Jardim Rosa ${ }^{\mathrm{I}}$ Jackeline Schultz Soares $^{\mathrm{I}}$ \\ Camila Soares Rosa Lemes ${ }^{I}$ Gisele Garcia de Sousa ${ }^{I}$
}

\section{ABSTRACT}

The success in micropropagation of Dendrobium phalaenopsis Deang Suree is high, but when transplanted into the greenhouse, their survival is minimal. To increase survival in production in the present study it was evaluated the effect of intermediate acclimatization for 30 days in a grow room utilizing the following luminosity conditions: 1- white fluorescent light $(B$ $\left(18.9 \mu \mathrm{mol} \mathrm{m}^{-2} \mathrm{~s}^{-1}\right) ; 2$ - white fluorescent light + red fluorescent light $\left(G R O-L U X^{\mathbb{B}}\right)(B V)\left(14.85 \mu \mathrm{mol} \mathrm{m} \mathrm{m}^{-2} \mathrm{~s}^{-1}\right) ; 3$ - red fluorescent light $\left(G R O-L U X^{\mathbb{B}}\right)(V)\left(9.45 \mu \mathrm{mol} \mathrm{m} \mathrm{m}^{-2} \mathrm{~s}^{-1}\right)$ and the control plants were accommodated directly in a greenhouse $\left(162.0 \mu \mathrm{mol} \mathrm{m} \mathrm{m}^{-2} \mathrm{~s}^{-1}\right)$. After this the leaves were characterized anatomically and the plants transferred to the control greenhouse. It was evaluated survival percentage and final number of roots, and calculated the relations between the final and initial values of fresh weight, number of leaves, length and diameter of the largest pseudo bulb, number of pseudo bulbs and longest root length. Only plants submitted to red light, were statistically better than the control in relation to the survival percentage and in relation to fresh weight, while the control showed a higher number of roots that plants acclimatized in this luminosity conditions. Intermediate acclimatization, using red light or red + white light, is recommended for D. phalaenopsis Deang Suree.

Key words: Orchidaceae, floriculture, luminosity conditions, in vitro cultivation.

\section{RESUMO}

O sucesso na micropropagação de Dendrobium phalaenopsis Deang Suree é alto, porém, quando transplantado para o viveiro, sua sobrevivência é mínima. Com o intuito de aumentar a sobrevivência na produção, no presente trabalho, avaliou-se o efeito da aclimatização intermediária, por 30 dias em sala de crescimento, sob as seguintes condições de luminosidade: 1luz fluorescente branca $\left(18,9 \mu \mathrm{mol} \mathrm{m} \mathrm{m}^{-2}\right) ; 2$ - luz fluorescente branca + luz fluorescente vermelha $\left(14,85 \mu \mathrm{mol} \mathrm{m}^{-2} \mathrm{~s}^{-1}\right)$; e 3-luz fluorescente vermelha $\left(9,45 \mu \mathrm{mol} \mathrm{m}^{-2} \mathrm{~s}^{-1}\right)$, o controle foi acondicionado diretamente em viveiro coberto $\left(162,0 \mu \mathrm{mol} \mathrm{m} \mathrm{m}^{-2} \mathrm{~s}^{-1}\right)$. Na sequência, as folhas foram caracterizadas anatomicamente e as plantas foram transferidas para o viveiro que continha o controle. Foi avaliada a porcentagem de sobrevivência e o número final de raízes, sendo calculadas também as relações entre os valores finais e iniciais de massa fresca, número de folhas, comprimento e diametro do maior pseudobulbo, número de pseudobulbos e comprimento da maior raiz das plantas aclimatizadas. Apenas as plantas submetidas à luz vermelha foram estatisticamente superiores ao controle, em relação à porcentagem de sobrevivência e relação de massa fresca, enquanto que o controle apresentou maior número de raizes que plantas aclimatizadas nessa condição de luminosidade. Aclimatização intermediária, utilizando luz vermelha ou a luz vermelha + branca, é recomendada para D. phalaenopsis Deang Suree.

Palavras-chave: Orchidaceae, floricultura, condições de luminosidade, cultivo in vitro.

\section{INTRODUCTION}

Most orchids are propagated by in vitro cultivation techniques. Despite the success of these techniques, a significant number of species of this family, likeothers, donotsurvive the transferconditions in vitro to ex vitro conditions, limiting the commercial production (HAZARIKA, 2003). Here it is shown that the utilization of an intermediate acclimatization phase using three luminosity conditions between in vitro culture and acclimatization promotes ex vitro survival in production of Dendrobium phalaenopsis Deang Suree.

IUniversidade Federal da Grande Dourados (UFGD), Faculdade de Ciência Agrárias (FCA), 79804-970, Dourados, MS, Brasil. E-mail: jc_sorgato@hotmail.com.*Corresponding author. 
The genus Dendrobium consists of approximately 1,500 species, almost all epiphytes, with wide geographical distribution. It comprises plants that are easily cultivated, adaptable to all kinds of weather, mostly blooming from late winter to early spring (LORENZI \& SOUZA, 2008; FARIA, 2010). In Mato Grosso do Sul, D. phalaenopsis Deang Suree produces stems with 8-16 buds, depending on the age of the plant, and its flowers, when open, have a diameter of about $5 \mathrm{~cm}$, flowering between March and July for approximately 30 days.

The acclimatization phase of these plants is very critical and delicate since, being still heterotrophic (showing low efficiency of the root system, reduced vascular competence, little or no functional stomata and cuticle not well formed) if exposed to an environment with high evaporative demand present reduced probability of survival (DEBERGH, 1991; ROMANO \& MARTINSLOUÇÃO, 2003; TAVEIRA, 2011; FARIA, 2012). This way, the use of treatments which precede the acclimatization is frequently needed.

Among the techniques of intermediate acclimatization it can be mentioned those developed by VILLA et al. (2006) with Rubus spp., SOUZA SOBRINHO et al. (2007) with Pennisetum purpureum Schum., NASCIMENTO et al. (2008) with Eugenia pyriformis, SCHUCK et al. (2012) with Vitis labrusca L., increased the survival rate of plants grown in vitro removing bottle caps, and the bottles, while still in a growth room for 2-5 days before ex vitro transplanting, subjecting the plants to lower humidity, resulting in faster adaptation of stomata than plants transplanted directly to the greenhouse.

Another intermediate acclimatization technique was developed by OTONI et al. (1995) with Passiflora edulis f. flavicarpa Degener and $\boldsymbol{P}$. incarnata L., COSTA et al. (2007) with Averrhoa carambola L. and MOURA et al. (2012) with Bowdichia virgilioides, enabled progressive adaptation of plants recently removed from containers airtight cultivation which were transferred to $e x$ vitro cultivation and covered them with transparent polypropylene provided with ventilation holes, creating an environment with a relative humidity higher than the greenhouse.

Since most epiphyte orchids are tropical forest components (RICKLEFS, 2010), exposed to low light intensities, the luminosity condition is another factor that influences their acclimatization as it causes metabolic responses, modulating morphogenesis of tissues and organs of plants in all stages of development (DIÁZ-PÉREZ et al., 1995; TAVEIRA, 2011).
The light is responsible for the processes of photosynthesis, photomorphogenesis and phototropism. In photosynthesis, peaks correspond to wavelengths relative to blue $(425-490 \mathrm{~nm})$ and red (650-680nm). Red, together with the extreme red (peaks between 710-740nm) are responsible for the processes of morphogenesis, while blue, violet (peaks between 400-425nm) and ultraviolet (peaks between 280-400nm) activate phototropism (KÄMPF, 2005; MAJEROWICZ \& PERES, 2008).

Most of the growth rooms for in vitro cultivation uses white fluorescent lamps (400-600nm) that are devoid of waves in the red band (KÄMPF, 2005). Because of the importance of the red light on photomorphogenesis, different authors have analyzed this wave length as a form of enabling increased growth and development of some plants.

The use of red light promoted elongation of in vitro cultivated Cattleya loddigesii (ARAÚJO et al. 2009), increased shoot length for a Cattleya hybrid (CYBULARZ-URBAN et al. 2007) and the use of blue and red LED (light-emitting diodes) caused an increase in Cymbidium growth (TANAKA et al. 1998). However, the use of red light reduced the longest root length and increased the mortality of Cattleya loddigesii during the acclimatization phase (GALDIANO JUNIOR et al., 2012).

The objective of this study was to evaluate the effect of intermediate acclimatization with different luminosity conditions in the survival and the development of Dendrobium phalaenopsis Deang Suree seedlings.

\section{MATERIALS AND METHODS}

The experiment was conducted at the Laboratory of in vitro cultivation and acclimatization area of the Faculdade de Ciências Agrárias (FCA) Universidade Federal da Grande Dourados (UFGD) during July 2011 to July 2012. The climate type is Am Köppen (Tropical monsoon), with average temperature in the coldest month below $18^{\circ} \mathrm{C}$ and in the hottest upper than $22^{\circ} \mathrm{C}$ and total annual rainfall between 1250 and $1500 \mathrm{~mm}$.

The study material consisted of seedlings of Dendrobium phalaenopsis Deang Suree, with 180 days, yielded from in vitro sowing, cultured on MS medium and kept in a growth room with an average temperature of $25 \pm 2^{\circ} \mathrm{C}$ and 12 hours of photoperiod, light intensity of $18.9 \mathrm{~mol} \mathrm{~m}^{-2} \mathrm{~s}^{-1}$ obtained by means of two white fluorescent lamps of $40 \mathrm{~W}$ each.

The seedlings were removed from culture flasks, washed in water until complete removal of the 
culture medium, and standardized in size $1.0 \pm 0.3 \mathrm{~cm}$. Afterwards they were evaluated in relation to fresh weight, leaves number, length and diameter of the largest pseudo bulb, number of pseudo bulbs and longest root length. Later, each individual was planted in a $50 \mathrm{~cm}^{3}$ polypropylene container, provided with holes for drainage, being used as a substrate mixture of sphagnum moss and coconut fiber $\left(1: 1 \mathrm{v}^{-1}\right)$.

After planting, a control set of 40 plants was placed directly in the greenhouse covered by two $50 \%$ shade screens $\left(162.0 \mathrm{~mol} \mathrm{~m}^{-2} \mathrm{~s}^{-1}\right)$, provided with a micro sprinkler irrigation high pressure system, without being submitted to intermediate acclimatization.

Three sets of 40 plants each were transferred to a growth room with controlled temperature and photoperiod $\left(12 \mathrm{~h}, 25 \pm 2^{\circ} \mathrm{C}\right)$ and submitted to intermediate acclimatization for 30 days under the following conditions, afforded by different lamps: 1- white fluorescent light (B) $\left(18.9 \mu \mathrm{mol} \mathrm{m}^{-2} \mathrm{~s}^{-1}\right)$; 2- white fluorescent light + red fluorescent light $(\mathrm{GRO}$ $\left.\mathrm{LUX}^{\circledR}\right)(\mathrm{BV})\left(14.85 \mu \mathrm{mol} \mathrm{m} \mathrm{m}^{-2} \mathrm{~s}^{-1}\right)$ and 3- red fluorescent light $\left(\mathrm{GRO}-\mathrm{LUX}^{\circledR}\right)(\mathrm{V})\left(9.45 \mu \mathrm{mol} \mathrm{m} \mathrm{m}^{-2} \mathrm{~s}^{-1}\right)$. After a period of intermediate acclimatization, the plants were transferred to the greenhouse containing the control.

For anatomical analysis of the effects of intermediate acclimatization, leaf tissue samples from plants submitted to different luminosity conditions in the growth room were collected and compared with plants recently removed from the in vitro condition. The leaves were cut into pieces of $5 \mathrm{~mm}$, fixed in FAA (35\% formaldehyde, glacial acetic acid and 50\% ethanol), and stored in refrigerator until the beginning of the dehydration process in alcoholic progressive series with tertiary butyl alcohol (DANKIN \& HUSSEY, 1985). After this process the fragments of leaves were infiltrated in paraffin and subsequently in paraplast. Cross sections, $10 \mu \mathrm{m}$ thick, were made in manual rotary microtome and were stained with safranin-orange G-fast Green FCF (HAGQUIST, 1974). After fitting the permanent slides, the images were analyzed using the computer application (AxioVision version 3.1) coupled to the ocular micrometer microscope.

During the definitive acclimatization, plants were weekly fertilized with 10-10-10 NPK $\left(2.0 \mathrm{~mL} \mathrm{~L}^{-1}\right)$, on leaves, and irrigated with a water slide of $3 \mathrm{~mm}$, divided into three applications of $1 \mathrm{~mm}$ each, rainfall volume discounted.

Twelve months after planting, the plants were evaluated for survival percentage and were removed from the substrate, washed in running water and evaluated for fresh weight, number of leaves, length and diameter of the largest pseudo bulb, number of pseudo bulbs, longest root length and final number of roots. In view of the interest in investigating the possibility of increasing the evaluated variables (except for the number of roots) the relations between final and initial values were calculated and these relations, initial and final values were considered in the statistical analysis.

It was used a completely randomized design with four treatments and forty repetitions with a plant. For statistical analysis it was used the computer application SISVAR (Statistical Analysis Software v.5.3. Universidade Federal de Lavras, Lavras, MG) and all variables were evaluated using analysis of variance and the averages were compared by the Tukey test to the $5 \%$ level of probability.

\section{RESULTS AND DISCUSSION}

There was significant effect $(\mathrm{P}<0.05)$ regarding the lighting conditions on the survival percentage on relations between final and initial fresh weight and the number of roots of Dendrobium phalaenopsis Deang Suree. For the other variables, there was no significant effect regarding treatment $(\mathrm{P}>0.05)$ and the observed values are: initial $\left(\mathrm{MF}_{\mathrm{i}}\right)=0.6 \pm 0.3 \mathrm{~g}$ and final fresh weight $\left(\mathrm{MF}_{\mathrm{f}}\right)=6.4 \pm 3.3 \mathrm{~g} ;$ initial $\left(\mathrm{CB}_{\mathrm{i}}\right)=2.1 \pm 1.9 \mathrm{~cm}$ and final length of pseudo bulb $\left(\mathrm{CB}_{\mathrm{f}}\right)=3.4 \pm 1.8 \mathrm{~cm}$; initial $\left(\mathrm{DB}_{\mathrm{i}}\right)=0.9 \pm 0.6 \mathrm{~cm}$ and final diameter of pseudo bulb $\left(\mathrm{DB}_{\mathrm{f}}\right)=1.2 \pm 1.1 \mathrm{~cm}$; initial $\left(\mathrm{CMR}_{\mathrm{i}}\right)=3.5 \pm 2.3 \mathrm{~cm}$ and final longest root length $\left(\mathrm{CMR}_{\mathrm{f}}\right)=13.2 \pm 4.5 \mathrm{~cm}$; initial $\left(\mathrm{NF}_{\mathrm{i}}\right)=4.6 \pm 1.8$ and final number of leaves $\left(\mathrm{NF}_{\mathrm{f}}\right)=7.3 \pm 2.3$; and initial $\left(\mathrm{NB}_{\mathrm{i}}\right)=2.3 \pm 1.9$ and final number of pseudo bulbs $\left(\mathrm{NB}_{\mathrm{f}}\right)=3.1 \pm 1.1$, all showing positive relations.

The highest average of survival percentage (SOBR) and relation of fresh weight (RMF), after a year of intermediate acclimatization in greenhouse, were observed in plants that were treated with fluorescent red light (V), and didn't differ statistically from those treated with white fluorescent light + red fluorescent light and those submitted to white fluorescent light (B) during the intermediate acclimatization period. The control treatment showed survival percentage and increase in fresh weight with a significant difference $(\mathrm{P}<0.05)$ only from treatment V (Table 1$)$.

Independently of the luminosity condition used in the intermediate acclimatization, the percentage of survival of the plants submitted to such 
Table 1 - Survival percentage (SOBR), final number of roots (NRF) and the relations between final and initial values of fresh weight (RMF), length of pseudo bulb (RCB), diameter of pseudo bulb (RDB), longest root length (RCMR), number of leaves (RNF) and number of pseudo bulbs (RNB)of D. phalaenopsis Deang Suree after 12 months. Dourados - MS, UFGD, 2012.

\begin{tabular}{lllllllll}
\hline Trat. & SOBR $(\%)$ & NRF & RMF & RCB & RDB & RCMR & RNF & RNB \\
\hline Control & $60.0 \mathrm{~b}$ & $15.9 \mathrm{a}$ & $10.6 \mathrm{~b}$ & $2.1 \mathrm{a}$ & $2.3 \mathrm{a}$ & $5.5 \mathrm{a}$ & $1.7 \mathrm{a}$ & $1.6 \mathrm{a}$ \\
B & $75.0 \mathrm{ab}$ & $11.7 \mathrm{~b}$ & $12.2 \mathrm{ab}$ & $2.0 \mathrm{a}$ & $1.6 \mathrm{a}$ & $6.2 \mathrm{a}$ & $1.7 \mathrm{a}$ & $1.4 \mathrm{a}$ \\
BV & $75.0 \mathrm{ab}$ & $13.1 \mathrm{ab}$ & $11.3 \mathrm{ab}$ & $2.5 \mathrm{a}$ & $1.5 \mathrm{a}$ & $4.4 \mathrm{a}$ & $2.0 \mathrm{a}$ & $1.5 \mathrm{a}$ \\
V & $87.5 \mathrm{a}$ & $12.1 \mathrm{ab}$ & $14.5 \mathrm{a}$ & $2.2 \mathrm{a}$ & $1.3 \mathrm{a}$ & $4.7 \mathrm{a}$ & $1.6 \mathrm{a}$ & $1.2 \mathrm{a}$ \\
CV(\%) & 50.5 & 16.8 & 17.0 & 21.3 & 22.4 & 26.1 & 2.1 \\
Average & 74.4 & 13.2 & 12.1 & 2.2 & 1.7 & 5.2 & 1.7 \\
DP & 43.8 & 4.6 & 4.9 & 1.4 & 1.8 & 3.1 & 0.7 \\
\hline
\end{tabular}

Averages in the same column with the same letter are not statistically different according to Tukey's test at $5 \%$ level of significance $\mathrm{B}=$ white fluorescent light $\left(18.9 \mu \mathrm{mol} \mathrm{m}^{-2} \mathrm{~s}^{-1}\right) ; \mathrm{BV}=$ white fluorescent light + red fluorescent light $\left(14.85 \mu \mathrm{mol} \mathrm{m} \mathrm{m}^{-2}\right)$ and $\mathrm{V}=\mathrm{red}^{-1}$ fluorescent light $\left(9.45 \mu \mathrm{mol} \mathrm{m} \mathrm{m}^{-1}\right)$

$\mathrm{DP}=$ Standard deviation .

pre-treatment was equal or higher than $75 \%$, a value considered quite satisfactory for commercial crops. The practice of intermediate acclimatization with $\mathrm{V}$ light provided a percentage increase of $27.5 \%$ over the control plants, a statistically significant difference (Table 1).

The results for the percentage survival observed in this study differ from those obtained by GALDIANO JUNIOR et al. (2012). The authors verified that plants of Cattleya loddigesii Lindl. cultured in vitro under red light (obtained by enveloping with a cellophane sheet the cultivation flask located under white fluorescent light), showed higher mortality rate during ex vitro acclimatization, attributing these results to the least amount of roots, to the lower level and in balance of chlorophyll types produced by plants when grown under these conditions.

The lowest values of RMF control are probably due to the high dehydration incurred by the plants at the beginning of the acclimatization which also decreased the percentage of survival of those submitted to this treatment. The highest number of roots was produced by plants that were not submitted to intermediate acclimatization, hence statistically similar results to those observed in acclimatized plants in BV light and V light. The acclimatized plants with B light presented the lowest numbers of roots compared to control (Table 1) these results differ from those reported by GALDIANO JUNIOR et al. (2012) and ARAÚJO et al. (2009) that reported fewer roots in Cattleya loddigesii Lindl. grown under red light.

The results related to the relation of weight, survival percentage and number of roots recorded in control allow us to infer that the stress of acclimatization induces the formation of a larger number of roots, since these organs are responsible for fixing the plant in the new substrate, in addition to providing the hydric and nutritional needs of the plant.

The red radiation generally promotes shoot elongation, as it is absorbed by phytochromes that are responsible for positive photoblastic seed germination, cauline growth and photoperiodic control of flowering (MAJEROWICZ \& PERES, 2008). This fact has already been noted in studies with Azorina vidalli (SILVA \& DEBERGH, 1997); Disanthus cercidifolius and cultivars of Rhododendron (MARKS \& SIMPSON, 1999); Prunus sp. (MULEO, 2001) and in Cattleya lodigessi (ARAÚJO et al., 2009). However D. phalaenopsis Deang Suree did not respond significantly with respect to the length of pseudo bulbs, relative to the treatments.

Independently of treatment used, final plant fresh weight was about 10 times higher than the initial fresh weight and the others relations between final and initial values were all positive $(\mathrm{RCB}=2.2$; $\mathrm{RDB}=1.7 ; \quad \mathrm{RCMR}=5.2 ; \quad \mathrm{RNF}=1.7 ; \quad \mathrm{RNB}=1.4)$ (Table 1), indicating that the conditions offered to the species are suitable for the first year of ex vitro acclimatization.

The results obtained in this research can be due to the fact that plants apparently perfect in vitro, exhibit a series of morphological anatomical and physiological changes. In these plants, the stomata are not functional and it respond slowly to water stress. In addition, the layer of protective wax on the leaves is minimal or absent, and the connection between the vascular system of the stem and adventitious roots 
is precarious to allow adequate flow transpiration (DIÁZ-PÉREZ et al., 1995; FARIA, 2012).

Independent of the treatment used, transverse sections of the leaves of D. phalaenopsis Deang Suree presented uniseriated epidermal cells of the adaxial side larger than the abaxial side, and a thin or absent cuticle (Figure 1A, B, C and D). According to STERN and JUDD (2001) in general, the leaves of orchids exhibit homogeneous chlorenchyma, which was observed in this experiment, since in all the slides it was not possible to delimit the parenchyma.

Despite the homogeneity of chlorenchyma, plants submitted to intermediate acclimatization showed cells that make up the mesophyll more organized, evident vascular bundles and more organized structured and epidermal cells. The organization of the epidermal cells in front view, appeared longitudinally elongated on the adaxial side and rounded on the abaxial side (Figure $1 \mathrm{~B}, \mathrm{C}$ and $\mathrm{D}$ ). However, in plants recently removed from the in vitro cultivation (Figure 1A), cells that compose the mesophyll and epidermis show some disorganization besides undeveloped vascular bundles.
According to HAZARIKA (2006), the poorly differentiated mesophyll and fragile vascular system of the leaves formed in vitro make these plants highly susceptible to stress during acclimatization. It follows clearly that in $\boldsymbol{D}$. phalaenopsis Deang Suree the best cellular organization of the mesophyll and the better structure of the vascular bundles obtained after thirty days of intermediate acclimatization may have reduced stress and facilitated the acclimatization.

\section{CONCLUSION}

The intermediate acclimatization in growth room for thirty days, using red light or red + white light, is recommended for Dendrobium phalaenopsis Deang Suree.

\section{ACKNOWLEDGEMENTS}

To Coordenação de Aperfeiçoamento de Pessoal de Nível Superior (CAPES), Fundação de Apoio ao Desenvolvimento do Ensino, Ciência e Tecnologia do Estado de Mato Grosso do

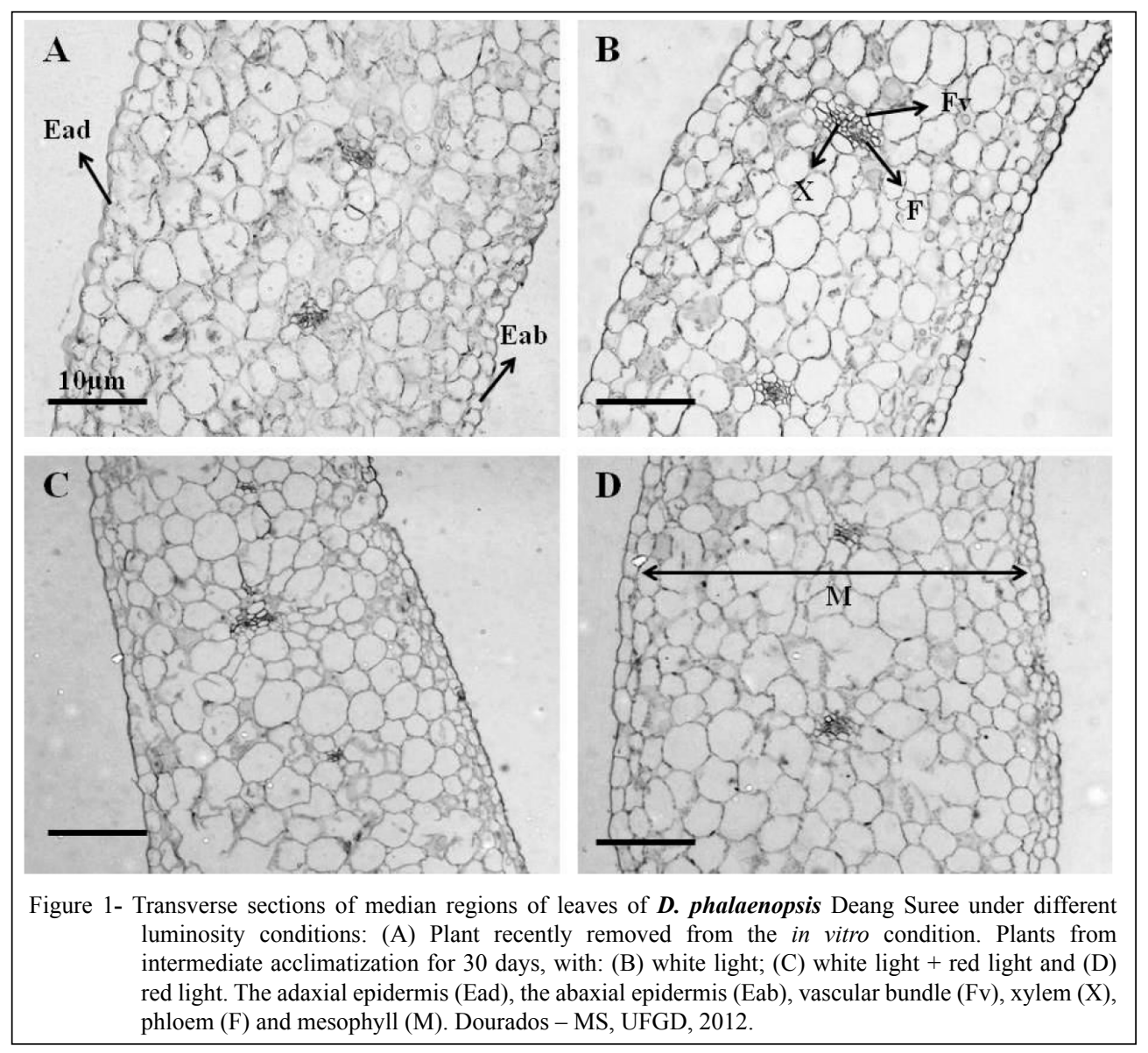

Ciência Rural, v.45, n.2, fev, 2015. 
Sul (FUNDECT) and Universidade Federal da Grande Dourados (UFGD) for the scholarships granted and assistance.

\section{REFERENCES}

ARAÚJO, A.G. et al. Crescimento in vitro de Cattleya loddigesii Lindl. em diferentes espectros luminosos associados com ácido giberélico. Ceres, v.56, n.5, p.542-546, 2009. Available from: $<$ http://www.ceres.ufv.br/ceres/revistas/V56N005P07807. pdf>. Accessed: Jan. 15, 2013. doi: 10.1590/S010384782012005000019 .

COSTA, N.P. et al. Semeadura in vitro e aclimatização de plântulas de caramboleira. Amazonian Journal of Agricultural and Environmental Sciences, n.47, p.211-220, 2007. Available from: <http://www.periodicos.ufra.edu.br/index.php/ajaes/article/ view/205/96>. Accessed: Aug. 2, 2012.

CYBULARZ-URBAN, T. et al. Effect of light wavelength on in vitro organogenesis of a Cattleya hybrid. Acta Biologica Cracoviensia, v.49, p.211-220, 2007. Available from: <http:// www.ib.uj.edu.pl/abc/pdf/49_1/14cybula.pdf $>$. Accessed: Aug. 12,2012 .

DANKIN, M.E.; HUSSEY, R.S. Staining and histopathological techniques in nematology. In: BARKER, K.R. et al. (Eds.). An advanced treatise on Meloidogyne. Raleigh: North Carolina State University, 1985. p.39-48.

DEBERGH, P.C. Aclimatization techniques of plants from in vitro. Acta Horticulturae, v.289, p.291-300, 1991. Available from: $<$ http://www.actahort.org/members/showpdf?booknrarnr=289 77>. Accessed: Aug. 11, 2012.

DIÁZ-PÉREZ, J. et al. Acclimatization and subsequent gas exchange, water relations, surviral and growth of microcultured apple plantlets after transplanting them in soil. Physiologia Plantarum, v.9, p.225-232, 1995. Available from: <http:// onlinelibrary.wiley.com/doi/10.1111/j.1399-3054.1995.tb00831.x/ full $>$. Accessed: Aug. 2, 2012. doi: 10.1111/j.1399-3054.1995. tb00831.x.

FARIA, R.T. et al. Cultivo de orquídeas. Londrina: Mecenas, 2010. 208p.

FARIA, R.T. Produção de orquídeas em laboratório. Londrina: Mecenas, 2012. 124p.

GALDIANO JUNIOR, R.F. et al. Crescimento in vitro e aclimatização de Cattleya loddigesii Lindley (Orchidaceae) com carvão ativado sob dois espectros luminosos. Ciência Rural, v.42, n.5, p.801-807, 2012. Available from: <http://www.scielo. br/pdf/cr/v42n5/a13212cr5881.pdf $>$. Accessed: Jan. 21, 2013. doi: 10.1590/S0103-84782012005000019.

HAGQUIST, C.W. Preparation and care of microscopy slides. American Biology Teacher, v.36, p.414-417, 1974.

HAZARIKA, B.N. Acclimatization of tissue-cultured plants. Current Science, v.85, n.12, p.1704-1712, 2003. Available from: $<$ http://www. currentscience.ac.in/Downloads/article_id_085_12_1704_1712_0. pdf>. Accessed: Aug. 2, 2012.

HAZARIKA, B.N. Morpho-physiological disorders in vitro culture of plants. Scientia Horticulturae, v.108, p.105-120, 2006. Available from: <http://www.deepdyve.com/lp/elsevier/ morpho-physiological-disorders-in-in-vitro-culture-of-plantsz2aXL1wJJ8?key=elsevier>. Accessed: Aug. 5, 2012.

KÄMPF, A.N. Produção comercial de plantas ornamentais. 2.ed. Guaíba: Agropecuária, 2005. 254p.

LORENZI, H.; SOUZA, H.M. Plantas ornamentais no Brasil. 4.ed. Nova Odessa: Instituto Plantarum, 2008. 1120p.

MAJEROWICZ, N.; PERES, L.E.P. Fotomorfogênese em plantas. In: KERBAUY, G.B. Fisiologia vegetal. 2.ed. Rio de Janeiro: Guanabara Koogan, 2008. 431p.

MARKS, T.R.; SIMPSON, S.E. Effect of irradiance on shoot development in vitro. Plant Growth Regulation, v.28, p.133-142, 1999. Available from: <http://download. springer.com/static/pdf/620/art\%253A $10.1023 \% 252$ FA $\% 25$ 3A1006276724956.pdf?auth66=1386777233 e31f83a2fa1a53b 6ec7638fb7c4f8e19\&ext=.pdf $>$. Accessed: Aug. 15, 2012. doi: 10.1023/A:1006276724956.

MOREIRA DA SILVA, M.H.; DEBERGH, P.C. The effect of light quality on the morphogenesis of in vitro cultures of Azorina vidalii (Wats.) Feer. Plant Cell Tissue Organ Culture, v.51, p.187193, 1997. Available from: <http://download.springer.com/static/ pdf/274/art\%253A10.1023\%252FA\%253A1005988621036.pdf?a uth66=1386777143 563b67e200e60ac8151fff98debe2681\&ext=. pdf>. Accessed: Aug. 11, 2012. doi: 10.1023/A:1005988621036.

MOREIRA da SILVA, M.H.; DEBERGH, P.C. The effect of light quality on the morphogenesis of in vitro cultures of Azorina vidalii (Wats.) Feer. Plant cell, tissue and organ culture, v.51, n.3, p.187-193, 1997. Available from: <http://link.springer.com/ article/10.1023/A\%3A1005988621036\#page-1>. Accessed: Aug. 8,2012 .

MOURA, L.C et al. Micropropagação de sucupira-preta por meio de gemas axilares. Pesquisa Agropecuária Brasileira, v.47, p.691-1698, 2012. Available from: <http://www.scielo.br/pdf/ pab/v47n12/03.pdf $>$. Accessed: Jan. 5, 2013.doi: 10.1590/S0100204X2012001200003.

MULEO, R. et al. Photoregulation of growth and branching of plum shoots: physiological action of two photosystems. In Vitro Cellular \& Developmental Biology - Plant, v.37, p.609-617, 2001. Available from: <http://download.springer.com/static/ pdf/106/art\%253A10.1007\%252Fs11627-001-0107-x.pdf?auth66 $=1386777025$ 51eb1f5cfe243031aa842634f9a37dbe\&ext=.pdf $>$. Accessed: Aug. 10, 2012. doi: 10.1007/s11627-001-0107-X.

NASCIMENTO, A.C et al. Micropropagação de uvaieira (Eugenia pyriformis Cambess): efeitos do BAP e AIB. RevistaVerde, v.3, n.2, p.20-26, 2008. Available from: <http://www.gvaa.org.br/revista/ index.php/RVADS/article/view/90/90>. Accessed: Aug. 10, 2012.

OTONI, W.C. et al. Somatic hybridization of the Passiflora species, $\boldsymbol{P}$. edulis f. flavicarpa Degener and P. incarnata L. Journal Experimental Botany, v.46, p.777-785, 1995. Available from: $<$ http://jxb.oxfordjournals.org/content/46/7/777.full.pdf + html $>$. Accessed: Aug. 15, 2012.

RICKLEFS, R.E. A economia da natureza. 6.ed. Rio de Janeiro: Guanabara Koogan, 2010. 570p.

ROMANO, A.; MARTINS-LOUÇÃO, M.A. Water loss and morphological modifications in leaves during acclimatization of 
cork oak micropropagated plantlets. Acta Horticulturae, v.616, p.439-442, 2003. Available from: <http://www.actahort.org/ members/showpdf?booknrarnr=616_67>. Accessed: Aug. 5, 2012.

STERN, W.L.; JUDD, W.S. Comparative anatomy and systematics of Catasetinae (Orchidaceae). Botanical Journal of the Linnean Society, v. 136, p.153-178, 2001. Available from: <http:// onlinelibrary.wiley.com/doi/10.1111/j.1095-8339.2001.tb00564.x/ pdf $>$. Accessed: Aug. 4, 2012.doi:10.1111/j.1095-8339.2001. tb00564.x.

SOUZA SOBRINHO, F. et al. Aclimatização de germoplasma de capim-elefante, pós cultivo in vitro. Ciência Agrotecnologia, v.31, p.11-15, 2007. Available from: <http://www.scielo.br/pdf/cagro/ v31n1/v31n1a01.pdf >. Accessed: Aug. 5, 2012. doi: 10.1590/ S1413-70542007000100001.

SCHUCK, M.R. et al. Aclimatização de plantas micropropagadas de videira cv. 'Bordô' (Vitis labrusca L.) em diferentes substratos.
Journal of Biotechnology and Biodiversity, v.3, p.206-212, 2012. Available from: <http://revista.uft.edu.br/index.php/JBB/ article/view/394/276>. Accessed: Jan. 20, 2013.

TANAKA, M. et al. In vitro growth of Cymbidium plantlets cultured under super bright red and blue light-emitting diodes (LEDs). Journal of Horticultural Science and Biotechnology, v.73, p.39-44, 1998 .

TAVEIRA, J.A.M. Novas tecnologias na aclimatização, formação e manejo de mudas. In: GERALD, L.T.S. Biofábrica de plantas: produção industrial de plantas in vitro. São Paulo: Antiqua, 2011. $383 p$.

VILLA, F. et al. Micropropagação da amoreira-preta (Rubus spp.) e efeito de substratos na aclimatização de plantas. Acta Scientiarum Agronomy, v.28, n. 1, p.47-53, 2006. Available from: $<$ http://periodicos.uem.br/ojs/index.php/ActaSciAgron/article/ view/1302/1037>. Accessed: Aug. 6, 2012. 